\title{
"Green Destination Tourism" Reviewed from Islamic Economic Perspective (Case Study in Pulesari Yogyakarta Tourist Village)
}

\author{
Robist Hidayat ${ }^{\text {a1, }}$, Taufik Riza Mahendra ${ }^{\text {b2 }}$, Intan Octavia ${ }^{\text {b3 }}$ \\ 1,2,3 Muhammadiyah University of Yogyakarta, Yogyakarta Special Region 55183 , Indonesia \\ ${ }^{1}$ robisth96@gmail.com, ${ }^{2}$ taufikriza86@gmail.com *; ${ }^{3}$ achfaorkha@gmail.com \\ * Corresponding author
}

\section{ARTICLE INFO}

Article history

Received 2020-02-03

Revised 2020-08-11

Accepted 2020-09-10

Keywords

Islamic economics

Green Destination Tourism

Industrial Sector

\section{ABSTRACT}

Natural tourism villages usually carry the concept of "go green and back to nature." One of the tours that apply this concept is in the Pulesari village, Yogyakarta, where it carries the concept of green tourism, which is one of the "green destination tourism spots." Therefore, the idea is interesting, especially on the impact of "green destination tourism," besides the phenomenon of "halal destination tourism." The phenomenon occurs due to the Indonesian topography, especially Yogyakarta. Since it is a tropical region, and currently the development of the Islamic economy is positive, leading to researchers conducting research on "green destination tourism," which is reviewed in an Islamic economic perspective and showing that the tourism village applies Islamic economic concepts where the transaction is far from gharar (unclear matter). Thus it has a positive impact and one of the alternative choices for the development of the "tourism industry sector" in accordance with Islamic sharia of transparent transactions without additional stuff. The method used by the researcher was a qualitative method, in which the researcher conducted a survey directly to tourist attractions to do interviews.

\section{INTRODUCTION}

Tourism is a temporary movement of a person to a place where they can live without the burden of thoughts and workloads (AJ Burkat in Damanik, 2006). Tourism has become an important sector in Indonesia's economic growth. The last few years the tourism sector has made a positive contribution both nationally and internationally, with the development of the tourism sector in a region or country it will certainly increase income. Based onThe Ministry of Tourism's Pocket Book (2016) states that the tourism sector has a large contribution to the national Gross Domestic Product (GDP). It is known that in 2014 the tourism sector contributed up to $9 \%$ or IDR 946.09 trillion, while foreign exchange from the tourism sector in 2014 reached IDR 120 trillion and contributed 11 million people to employment opportunities.Empowerment in tourism in improving the community's economy has many positive impacts, but not a few negative ones that arise. In recent years the green destination tourism brand has emerged and has become a focus as an effort to minimize environmental damage as a result of an increase in the tourism sector, plus Indonesia, which is known as an agricultural country in the world, has become commonplace if green destinations exist.

Islam is a religion in which all human activities and behavior have been regulated in the Qur'an and Hadith. In all human activities, Islam requires that it is not only worldly but also spiritual. Hasanuz Zaman (1984) in his book "Economic Function of an Islamic State" defines Islamic Economics as follows "Islamic Economics is the knowledge and applications and rules of the shariah that prevent in justice in the requisition and disposal of material resources in order to provide satisfaction to human being and enable them to perform their obligations to Allah and the society "explains that Islamic economics is the knowledge, application and rules of sharia that prevent injustice to give satisfaction to humans and enable them to perform obligations to Allah. 
Not only justice, in the letter Ar-Rum verse 41 which reads:

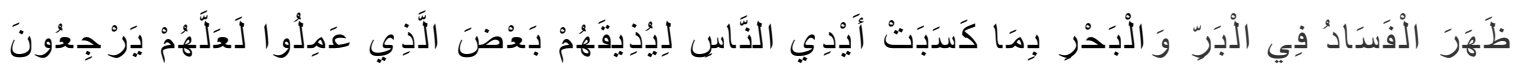

"It has appeared that the damage on land and at sea was caused by the actions of human hands, so that Allah will feel for them a part of (the result) of their actions, so that they will return (to the right path)."

It has been explained that Islam prohibits humans from doing damage in all activities including the economy. One of the tourism sectors in Yogyakarta which has become a green destination tourism is Pulesari Tourism Village. In this location, tourists can get freshness and beautiful views of the surrounding nature, and several tourism products that tourists can enjoy in the form of agility games, outbound, camping ground, joglo houses \& homestays. From the activities in utilizing its nature, Pulesari Tourism Village has indirectly had an impact on economic transactions on local communities.

According to the United Nations Conference on Environment and Development (UNCED), in Nurhidayati (2007), sustainable tourism is development that is able to meet the needs of today's life without reducing the ability to meet the needs of future generations. Self-tourism according to RI Law no. 10 of 2009, namely travel activities carried out by a person or group of people by visiting places for recreational purposes, self-development, or learning the unique characteristics of the tourist attractions visited in a temporary period.

Tourism is a movement to find a place out of habit at home and work, activities to live and enjoy the existing facilities that tourists need in a short time (Cooper et all). According to Lundberg, quoted by SemuelHatane (2007), explains that tourism is someone who is traveling from home and company in a way to facilitate or facilitate or make a trip enjoyable.(Besra, 2015)".

According to Hasan (2014) green tourism is tourism that focuses on tourism villages, agrotourism, green guest houses, green hotels, nature tourism and the like. As an alternative form of tourism, green torism focuses on calculating the amount of capacity, education, nature conservation and regional development, as well as specific regional activities.(Hasan, 2014). An area or area that is eligible to become a green tourism destination if it has criteria based on nature, supports conservation, is sustainable, and has environmental education (Weaver in Hasan, 2014). The operational aspects of the concept developed by Hasan (2014) include a vision built through ecological, commercial, social, and cultural spirits. Differentiation in accordance with the conditions emphasizes environmental preservation, the need to protect culture and the environment, the need to foster long-term productivity and the need to achieve a balance of economy, nature, society and custom as a value for citizens' attitude

Mathienson and Wall in Sunaryo (2013) several principles of sustainable and environmentally friendly tourism, including aspects of physical environmental indicators, socio-cultural aspects, and aspects of economic indicators. Therefore, sustainable development is expected to be able to produce innovations in building an economy that is useful for society without neglecting environmental problems. Sudarmo (2006) argues that developing tourism is a separate obstacle for local governments, especially in managing tourism destinations that are in accordance with the culture of the local community. In addition, this tourism concept is not only a government job. However, also non-governmental organizations and educational institutions at the school or university level.

Tourism is an integrated part of national development carried out in a systematic, planned, integrated, sustainable and responsible manner while still providing protection for religious, cultural values that live in society, sustainability and quality of the environment, as well as national interests. (Sukmawan, Rizal, \& Rohman, 2018). As muamalah that is allowed in Islam, the tourism sector must be developed as long as it does not conflict with the principles of noble values, as well as Islamic ideal values of cleanliness and discipline.(Arifin, 2016) 
Islamic economics as a science that emerged through in-depth study, which initially occurred pessimistic attitude related to the existence of Islamic economics in everyday life (Al ArifRianto, M. Nur, 2010). The goals achieved in an Islamic economic system include meeting basic human needs, ensuring equality, preventing the concentration of wealth, complying with moral values, and ensuring the stability of economic growth (Al ArifRianto, M. Nur, 2010). According to Choudry (in al Arif, Rianto, M. Nur, 2010), the policies that are the basis of the Islamic economic system are the prohibition of usury, the application of mudharabah, the prohibition of excessive consumption, and the establishment of institutions for distributing wealth.

The concept of Islamic economics is based on teachings sourced from the Koran and the Prophet's Hadith (Idri\&Tutik, 2008: 9). Various theories of Islamic Economics in the Economic System. Aspects related to Islamic economics cannot be separated from the provisions of these two sources. There are several universal values in Islamic economics which become the foundation for economic development and as a starting point for economic policies among Muslim communities which are extracted from and based on both. Universal values in Islamic economics are: 7. al-tauhid (faith), 2. al-'adl (justice), 3. al-nubuwah (prophecy), 4. al-khilafah (government), and 5. alma'ad (return / result). These five values are the basis of inspiration for compiling Islamic economic propositions and theories (A. Karim, 2003: I7). According to KhurshidAhmad, The universal values of Islamic economics as well as a philosophical foundation for the development of an Islamic economy are: (1) al + auhid (the oneness and majesty of God), (2) al-rububiyah (God's arrangement of natural resources), (3) al-khilafaft (government), and (4) ultazkiy ah (cleanliness, purity, and development) (Ahmad, 1982: 221). The universal values above can then be classified into six types, namely: (I) al-tauhid (in the meaning of al-uluhiyahdanrububiyah), (2) al-'adl (justice), (3) alnubuwwah (prophecy), (4) al-khilafah (government), (5) al-tazkiyah (cleanliness or purity), and (6) al-ma'ad (return, results, days later). These six universal values characterize and become the starting point for all norms, rules, policies, and solutions to Islamic economic problems. Among the universal values of Islamic economics are as follows: 1. The value of Tawhid (al-Uluhiyah and Rububiyah) Tawheed is the main essence of Islamic teachings in the form of recognition that there is no god but Allah, the only substance that has the right to be worshiped. Tawhid is divided into two kinds, namely tauhid al-uluhiyah and tauhid al-rububiych. Tauhid al-uluhiy ah means affirming Allah, being childless and not being begotten, having no partners or partners. In this view, Allah is absolute God. He pervades and transcends all things. He is God and besides Him must worship Him. Tauhid al-rububiyah refers to Allah as God, creator and regulator of the universe. The existence of God in this sense can be known primarily through His creations (Idri\&Tutik, 2008: 24). In Islam, The main principle in human life is Allah SWT, as the One Supreme Being. Meanwhile, humans are Allah's creatures who are created in the best form. In accordance with the essence of human form as khuff " $n$ in the life of the world, namely carrying out the duties of the caliphate in

The framework of devotion to the Creator. Humans also have an obligation to create a society that is well-connected with Allah by fostering a harmonious community life and maintaining religion, reason, and culture (Shihab, 2000: 166). is defined as a condition when there is equal behavior in the eyes of the law, equal compensation rights, the right to live properly, the 'right to enjoy development' and the absence of any aggrieved party and there is a balance in every aspect of life. Justice can produce balance in the economy by eliminating the gap between the owners of capital (the rich) and those in need ' Although of course Islam does not advocate economic equality and acknowledges the existence of economic inequality between individuals (Sudarsono, 2003: 107). The form of justice in the economy is related to four things, namely exchange justice, distributive justice, social justice, and legal justice (Idri\& T Tutik, 2008: 39). For this reason, it is necessary to uphold the principle of justice in every aspect of life, especially in the economic sector. 3. Governance (Khilafah) In Islam, the government plays a very important role in the economy, namely ensuring that activities run correctly without injustice. The government has a mixed role in the economic activities carried out by individuals, either to supervise these activities or to regulate or carry out several kinds of economic activities that individuals are unable to carry out (Assal and Abdul Karim, 1999: 101) 'Apart from universal values, there are also characteristics of Islamic economics, namely economics related to faith, sharia and Islamic Economics in the Moral 
Economic System. There are three areas of Islamic teachings that guide humans in carrying out their lives, including the economic field, namely: faith, morals, and sharia. The factor of faith has a strong influence on a person's soul and attitude to life, moral factors make a person feel human (humanist) and responsible for their every behavior, and the sharia factor functions as a person's command system in socializing with the wider community (al-Nabahan, 2002: 2-3).

Realizing the tourism philosophy, as explained earlier, is not easy because it requires professional personnel. This is because on the one hand, tourism is required to increase friendship between nations, and on the other hand, it is required to instill love for the country and strengthen the unity and integrity of the nation. Thus, efforts to realize these mandates require adequate education and training for all parties involved in tourism activities. Meanwhile, education and training in the tourism sector is complex. Thus, if the PATO / WTO conference in Bali considers tourism activities as a global challenge which includes six challenges. 15

1. Multi-disciplinary tourism activities.

2. It takes a lot of money and time for education and training in the field of tourism.

3. Difficulty aligning skills required and economic reality.

4. Difficulty providing educated personnel on the structure of the tourism industry.

5. The number of countries and educational institutions that must adopt a more professional approach to education and training in tourism (Syahriza. 2014).

Tourism in Arabic comes from the word rihlah which means travel, while other words of rihlah are expressed by safara and sara, where the derivation of the word is mentioned 27 times in surah al-qashash: 29, al-Thur: 10 (in the form of fi 'ilmudhai' and masdhar), Yusuf verses 10, 19, and 109, al-Hajj 46, al-Rum 9 and 42, Fathir 44, al-Mukmin 21 and 82, Muhammad 10, Ali Imran 137, al-An ' am 11, al-Nahl 36, al-Naml 69, al-ankabut 20, saba '18 (expressed in the form fi'ilamr and mashdar), al-Kahfi 47, Yunus 22, al-Ra'd 20, al- Takwir 3, Thaha 21, and al-maidah 96 (Abdul Baqi: 475 in Syahriza. 2014).

We can find the term rihlah in the Qur'an surah Quraish [106] verse 2 "(Ie) their custom of traveling in winter and summer.".Rihlah in its interpretation is a journey undertaken in fulfilling business affairs (Shahhriza, Rahmi. 2014). According to Fazrulrahman, the Quraish market share to Syria, Turkey, Bulgaria, Greece, Eastern Europe, Yemen, Oman, or in cooperation with Chinese and Indian traders, stopped at the port of Aden.17 When viewed from the business map developed by the Quraish which was so broad, it appears that they were able to put down the principles of cross-country trade or go to the global market. They went on to become global players, not just good at drums(Shahhriza, Rahmi. 2014).

Word safarain the Koran has several meanings including (al-Ashfahaniy, 2002: 412 in Syahriza, 2014):

1. Open and clean dirt dust.

2. Shows a certain color as in surah al-Muddatsir verse 34 .

3. Traveling from one place to another as in surah an-Nisa ' 43.

4. Has a meaning as a book as in sura al-Jumu'ah 5.

As for sara in the Koran has meaning (al-Ashfahaniy, 2002: 412 in Syahriza, 2014):

1. It is an order, effort (ikhtiar), and a desire to travel as in letter Jonah verse 22.

2. Has the meaning of several people as in the letter Jonah 19.

3. Means to subdue or conquer as in the letter at-Takwir 3 which is described in the description of subduing mountains.

4. An instinctive condition (gharizah) or something that is strived for (muktasyabiyah) which is in someone's self as expressed in Surah Thaha verse 21

In human life, Islam does not prohibit a person from traveling from one place to another, Islam always calling for a journey to produce goodness in the world and the hereafter (Syahriza, Rahmi. 2014). Allah SWT in the verse that has been conveyed above calls on humans to travel to other places, both close and far, accompanied by paying attention and tadabbur. By paying attention and telling every thing that is seen, these humans always remember their position as servants of Allah 
SWT, so that it is not only pleasure that a person who travels gets, but also gets a reward or reward from Allah SWT.

Munurut Dr. Abdul Hakam Ash-Sha'idi in his book entitled Ar-Raihlatu fi Islami,Islam divides several travel activities or trips into five groups (Syahriza, Rahmi. 2014):

1. Traveling to seek and obtain safety is like moving from a place full of bad acts.

2. Traveling with religious purposes such as studying, carrying out the pilgrimage, jihad in the way of Allah, making pilgrimages to noble places, visiting or visiting relatives, relatives and relatives for the sake of Allah SWT.

3. Traveling in search of worldly benefits such as earning a living and making ends meet.

4. Traveling to create peace in society such as mediating fights, preaching and disseminating religion, and deliberation.

5. Travel for pleasure.

Islam in terms of tourism comes to elevate understanding of tourism and link it to its benefits and good goals, including (Syahriza, Rahmi. 2014):

1. Associating tourism with worship, so that Islam provides travel as an option of worship. Namely to meet the needs of the Haj and Umrah pilgrimages.

2. The existence of travel, in Islam can be said to have a relationship with science and knowledge.

3. Travel in order to take a trip and a warning.

4. Journeys in the context of spreading the religion of Islam carried out by scholars, namely like preaching

5. Safar or travel or tours to contemplate the beauty of Allah SWT's creation.

Tourism is an activity recommended by syara 'because human nature in life does not melt in performing mahdhah worship which time, the amount of implementation has been determined by syara'. Syara 'also encourages Muslims to get to know the surrounding nature, so that if the tourism activity is able to make the perpetrators more familiar with the creator, to protect the surrounding environment more, this is of course highly recommended because the meaning of worship is not only mahdhah worship but is included in it.ghairumahdhah worship. Tourism activities intersect with economic activity, of course this requires serious handling so that what we get is not only tourism activities but is able to build a strong economy through these tourism activities. (Shahhriza, Rahmi. 2014).

The tourist village basically carries the concept of go green and back to nature and green destination torism. One of the tourist villages in Yogyakarta is Pulesari Tourism Village. This village can be said to be a green destination for tourism because of the potential of the village to produce food from the basic ingredients of salak, as well as many activities such as outbound, fun fame, trekking and river tourism.(Akram et al., 2013).It becomes interesting because it sees the impact of a tourist village as a green destination for tourists in Yogyakarta. Because seeing the many benefits obtained by the existence of tourism on the community's economy, government, and also the economy based on divinity. Therefore, the researchers conducted a problem formulation Pulesari Village development strategy is part of green destination tourism and how green destination tourism can be viewed from an Islamic economic perspective, as for the objectives that the researchers want to get, namely to find out the development strategy of Pulesari Village as a green destination tourism and Knowing whether green destination tourism can be viewed from an Islamic economic perspective.

\section{METHOD}

This research was conducted using descriptive qualitative analysis method, which seeks to describe and interpret the object of research according to the data obtained from available sources. The data and information used in this study were obtained through literature and field studies. A qualitative research is research in its use involving a natural setting, with the intention of being able to interpret a phenomenon that occurs and is carried out by involving various kinds of applicable 
methods. (Moelong, 2012) In addition, it also states that qualitative research is research as a way of understanding a phenomenon about what is experienced by the object of a study, for example behavior, perceptions, motivation of a person, an action and others holistically, in this way so that it can be described in the form of a word and also in a language that is understood, in a specific natural context and by utilizing various kinds of scientific methods. From the explanation above, the researcher used a qualitative method to describe the Pulesari Tourism Village in Yogyakarta as a green destination for tourism, so that there are results that can be studied further to get the information needed. In this study, researchers will collect data, assess data, describe data, and draw conclusions based on an objective analysis attitude (Yusuf, A. Muri, 2014), namely primary data obtained from interviews conducted with the management of Pulesari Tourism Village. This primary data was used to find out the real situation in Pulesari Tourism Village at the time of the interview. Descriptive data, namely the data obtained is presented in the form of sentences.

Interviews were conducted with respondents through question and answer which consisted of several questions to get maximum results and secondary data obtained from the manager in the form of a questionnaire containing the Pulesari tourism village development strategy and other important information that could support research. In addition, the method used by researchers is data processing techniques obtained from interviews, observation, and documentation studies. Collected to be further described in a directed and systematic manner. Furthermore, it is carefully reviewed to find the advantages and disadvantages of the research. As for the validity and credibility of this study, namely obtaining the information directly from the community concerned so as to obtain concrete information. Apart from that, he also conducted direct interviews with the agencies in charge of this research in order to obtain good data as well as what he wanted. In addition, triangulation is also used, which is a technique to check the validity of data that can be used from something else and the triangulation that researchers use is triangulation with sources, where this triangulation is how to compare and check back the degree of confidence of a information that can be obtained through time and something different in a qualitative study (Moelong, 2012)

\section{List of Interviews}

The interview was conducted with Bachelors as the chief manager of the Pulesari tourism village which was conducted on November 28, 2019. The list of questions asked included:

1. When did tourism in Pulesari village exist?

2. What are the concerns or the background for the initiative to make Pulesari Village a Tourism Village?

3. What is the geographical location of Pulesari Village?

4. What rides are available in Pulesari Tourism Village?

5. How is the income of the residents around the tourist attractions in Pulesari village before and after becoming tourist attractions?

6. How are the efforts made by the manager to avoid crimes that occurred, especially those related to immorality?

7. What is the future strategy to make Pulesari Tourism Village even better?

8. And for income, how do managers distribute income to local residents?

\section{RESULT AND DISCUSSION}

Pulesari Tourism Village was established on November 9, 2012, seeing the village's natural resources which are very supportive so that people want to find other sources of income because basically the livelihoods of the people of Pulesari Village are agribusiness in the field of planting salak, employees and employees. the geographical location of the village on the slopes of Mount Merapi, about $12 \mathrm{~km}$ from the top of the mountain. Because seeing the impact of the eruption due to the eruption of Mount Merapi which is now a tourist attraction. Make the village community want to make their village a regional tourist attraction. With a village area of more than 20 hectares consisting of salak farming, housing, public infrastructure and others. At the time of 2012 the bestselling branding was the tourist village. There are 48 houses that have gradually become homestays. For the use of natural resources in addition to farming, the community also uses two rivers to become a vehicle for playing, besides rivers there are also natural caves, waterfalls, and 
other educational vehicles. However, the added value is that in Pulesari Village, there are cliffs that are not owned by other tourist villages. In terms of culture, Pulesari Tourism Village greatly elevates the village's local wisdom which can be seen in a certain time, there are traditional, religious, and cultural ceremonies. However, the culture that is promoted is one of the branding and selling points of Pulesari Tourism Village. However, the added value is that in Pulesari Village, there are cliffs that are not owned by other tourist villages. In terms of culture, Pulesari Tourism Village greatly elevates the village's local wisdom which can be seen in a certain time, there are traditional, religious and cultural ceremonies. However, the culture that is promoted is one of the branding and selling points of Pulesari Tourism Village. However, the added value is that in Pulesari Village, there are cliffs that are not owned by other tourist villages. In terms of culture, Pulesari Tourism Village greatly elevates the village's local wisdom which can be seen in a certain time, there are traditional, religious, and cultural ceremonies. However, the culture that is promoted is one of the branding and selling points of Pulesari Tourism Village.

The rides offered are educational fun gamein which there is a tracking river, there are several rides including the guyang bridge, then passing through the bamboo under which there is a water pool, spider web, rain hut, susukban, and spider web. Other rides include children's games such as stilts, gobaksodor, and other children's games. There are vehicles with crafts and skills in the form of education to make barking baskets, painting, batik, religious arts and cultural arts such as dancing.

The condition of the community before the tourism village existed only relied on the income obtained from agricultural products and became employees. After the existence of a tourist village, the economy of the community has increased. Because all the elements that are owned by the residents become the selling value of the house, the shelter, agricultural land and human resources. Then another income, namely mothers who were initially unemployed were made as cooks. Because there are also regulations that recommend a tourist to buy light or heavy meals in Pulesari Village as well. While the social pattern is made an effort not to be eliminatedin various agenda of activities. Because remembering that Pulesari village tourism does not put social branding on the tourism agenda. The tourists who came to the village were immediately welcomed by the community to introduce how to socialize in the village.

Efforts made by the manager to avoid immoral acts are by reminding that homestayWesaPulesari is different from villas or inns. Tourists who enter the village are directly plotted in the homestay which is for men only and women for women only. Because remembering that someone had tried to commit immoral crimes in the village of Pulesari. Other efforts such as combining residents' houses with homestays are also useful to overcome this problem. So that tourists have a sense of shame in committing crimes. Even if it is in a situation that forces women to mix with men, it is required to bring evidence such as family cards and marriage books. so that the goal of the tourist village manager is not to cross religious or social norms.

The future strategy is for the management to strive to be sustainable to the next generation in the sense that at this time their parents who handle the tourism village will continue to their children and grandchildren. In terms of vehicles, there are renovations and innovations without eliminating the main elements andbrandingexisting. Because like the Panglipuran village in Bali even though the times are progressing, it will not be able to change the culture that has been implanted in each of its residents. This effort is what becomes the future plan of the tourist village manager, but also does not ignore the times that are happening.

For revenue sharing, which is managed openly, a section for administrators, managers, tour guides, social funds section, development funds, and for the government, in this case we can comply with the Islamic economic perspective, namely in terms of managing the tourism village in accordance with the principles sharia, for example gharar. Operationally gharar is defined as the two parties do not have certainty about the goods that are the object of the transaction, both in terms of quality, quantity, price, and delivery time of the goods, so that there are parties who feel their rights are disadvantaged, in this case the researchers do not encounter such things because in village management The tour is clear and there is proof of all transactions, we know that the 
Maqāșid (objective) for the prohibition of gharar is that if an activity or condition can cause a loss, disputes, and hostility between the parties concerned. However, the prohibition on gharar applies to mu'âwadah (business) transactions, and does not apply to tabarru '(social) transactions. What is meant by gharar is the uncertainty of profit or loss in business and investment (Elif P, 2017).

\section{CONCLUSION}

Tourism is an integrated part of national development carried out in a systematic, planned, integrated, sustainable and responsible manner while still providing protection for religious, cultural values that live in society, sustainability and quality of the environment, as well as national interests. (Sukmawan, Rizal, \& Rohman, 2018). As muamalah that is allowed in Islam, the tourism sector must be developed as long as it does not conflict with the principles of noble values, as well as Islamic ideal values of cleanliness and discipline.(Arifin, 2016).

Tourism is a temporary movement of a person to a place where they can live without the burden of thoughts and workloads (AJ Burkat in Damanik, 2006). Tourism has become an important sector in Indonesia's economic growth. The last few years the tourism sector has made a positive contribution both nationally and internationally, with the development of the tourism sector in a region or country it will certainly increase income.

The strategy in the future is that the manager strives to be sustainable to the next generation in the sense that at this time their parents who handle the tourism village will continue to their children and grandchildren. In terms of vehicles, there are renovations and innovations without eliminating the main elements and existing branding. Because like the Panglipuran village in Bali even though the times are progressing, it will not be able to change the culture that has been implanted in each of its residents. This effort is what becomes the future plan of the tourist village manager, but also does not ignore the current developments.

After the above explanation, it can be concluded that Pulesari Tourism Village as a village whose branding is Green Destination Tourism in Yogyakarta has a sufficient strategy to sustain it in the future, such as investment cooperation with the real private sector, local government support and sustainable management. On the other hand, the strategy that is currently being developed is the innovation of several vehicles that can become a magnet for tourists without eliminating the element of natural tourism, from an Islamic economic perspective it can be said that Pulesari Tourism Village carries out clear transactions and investments in accordance with sharia principles, one of which is not contains elements of gharar.

\section{REFERENCES}

Akram, H., Si, M., Afifi, M., Basuki, P., Santoso, HB, Com, M.,. . Nurabiah, M. (2013). National Seminar on Green Tourism and Economic Development (Green Tourism and Economic Development).

Al-Qur'an Al-Assal, Ahmad Muhammad and Fathi Ahmad Abdul Karim. 1999. Systems, Principles and Goals and Objectives of Islamic Economics. Bandung: Faithful Library.

Al-Nabahan, M. Faruq. 2002. Islamic Economic System: Options after the Failure of the Capitalist and Socialist Economic System. Yogyakarta: UII Press

Arifin, J. (2016). Al-Quran and Sunnah Insights on Tourism. Journal of An-Nur, 4 (2).

Besra, E. (2015). Potential of culinary tourism in supporting tourism in the city of Padang. JRAB: Journal of Accounting \& Business Research, 12 (1). 
Government pocket book 2016 (in the final report on the impact of the tourism sector on the Indonesian economy)

Burkart, AJ, \& Medlik, S. (1981). Tourism: past, present and future. Tourism: past, present and future., (Ed. 2)

Cooper, Chris and Stephen Jackson. 1997. Destination Life Cycle: The Isle Of Man Case Study. In the Earthscan Reader in Sustinable Tourism. United Kingdom: Earthscan Publications Limited.

Fardiansyah, Elif. 2017. Investment in Islamic Economic Perspective: Theoretical and Empirical Approaches. Economica: Islamic Economic Journal Vol. 8 No.2

Hasan, A. (2014). Green Tourism. TOURISM MEDIA JOURNAL: Forum for Tourism Information, 12 (1).

Idri, \& Tutik Quarter Point. 2008. Principles of Islamic Economics. Jakarta: Lintas Pustaka

Illy Yanti and Rafidah. 2009. Islamic Economy In Indonesian Economic System (Study of Islamic Economic Principles in KHES and Their Implementation of National Economy). CONTEXTUALITY VOL 25 No 1

Karim, Adiwarman. 2003. Islamic Economics: A Contempore Study. Jakarta: Gema Insani Press

Sukmawan, S., Rizal, MS, \& Rohman, MF (2018). Kampung Kulservasi (Culinary And Conservation) Wanamerta, Tengger: The Concept Of Green Tourism. Indonesian Cultural Studies, 2 (2), 99107.

Syahriza, Rahi. 2014. Sharia-Based Tourism (Study the Meaning of Sara's Word and Its Drevasion in the Al-Quran). Human Falah: Vol 1 No. 2

Hasan, Ali. "Green Tourism."Tourism Media Journal: Forum for Tourism Information 12.1 (2014).

Matienson A and Wall G. 1982. Tourism: Economic, Physical, and Social Impacts. New York. Longman Group Limited.

Nurhidayati, 2007.Community based tourism as an approach to sustainable tourism development. Journal of society, culture and politics. vol20 (3) p.31-44

Moleong, Lexy. 2012 Thirty Printing. Qualitative Research Methods, Bandung: PT. Youth Rosdakarya, p. 5

Sunaryo, Bambang. 2013. Tourism Destination Development Policy; Concept and Application in Indonesia. Yogyakarta: Gavamedia

Yusuf, AM (2016). Quantitative, qualitative \& combined research methods.Prenada Media.

Weaver, D. 2012. Ecotourism. Australia: John Wiley \& Sons. p 15

\section{Other Sources}

http://www.kemenpar.go.id/post/kajian-dampak-sektor-pbPariwisata-terhadap-perekonomiindonesia accessed in July 2019

https://visitingjogja.com/12734/desa-wisata-pulesari/accessed in July 2019 